\title{
Forgotten Nutritional Disease may Mimic Metabolic Disorders Scurvy
}

Işıl Özer ${ }^{1 *}$, Zehra Kılınçıı², Gülden Gökçay³, Tolunay Baykal ${ }^{3}$, Mübeccel Demirkol ${ }^{3}$ and Mehmet Müjdat Uysal'

${ }^{1}$ Medeniyet University Göztepe Teaching and Research Hospital Children's Clinic, Kadıköy/ Istanbul/Türkiye

'Istanbul University, Istanbul Medical Faculty, Children's Hospital, Turkey

3/stanbul University, Istanbul Medical Faculty, Children's Hospital, Division, Nutrition and Metabolism, Turkey

${ }^{4}$ Istanbul University, Istanbul Medical Faculty, Department of Biochemistry, Istanbul, Turkey

\author{
Abstract \\ Vitamin $\mathrm{C}$ is the cofactor in biosynthesis of collagen, catecholamines and iron metabolism. The clinical features of \\ scurvy may resemble metabolic disorders and hamper early diagnosis.
}

A 2-year, 5-months old male child was admitted to hospital with complaints of growth retardation, irritability, joint deformities, and frequent illness. Severe malnutrition, coarse facial appearance, gingival hypertrophy, organomegaly, osteoporosis and anemia were detected.

Screening for inborn errors revealed generalized aminoaciduria and elevated blood free carnitine. His dietary history revealed poor consumption of vitamin C. Vitamin C level was $0.05 \mathrm{mg} / \mathrm{L}$ ( $\mathrm{n}: 4-21)$ in plasma, $2.85 \mathrm{mg} / 24$ hour $(\mathrm{n}: 10-30)$ in urine, and $1.03 \mathrm{mg} / 6$ hours in urine after intravenous loading. The patient was given $200 \mathrm{mg} /$ day vitamin $\mathrm{C}$ orally. Irritability and bone sensitivity decreased after the first two days.

Clinical features in scurvy resemble symptoms observed in some metabolic disorders. Careful clinical evaluation, dietary history and vitamin $\mathrm{C}$ assay may exclude uneccessary metabolic work-up.

Keywords: Scurvy; Inborn errors of metabolism; Painful hip; Osteoporosis

\section{Introduction}

Vitamin Cis the cofactor in biosynthesis of collagen, catecholamines and iron metabolism (Figure 1). The clinical features of scurvy may resemble metabolic disorders.

The most familiar role of vitamin $\mathrm{C}$ is reduction and transfer of iron to transferrin and ferritin. Vitamin $\mathrm{C}$ is effective in intestinal absorption of non-haem iron. If vitamin $\mathrm{C}$ is not added to the treatment, administering iron alone does not achieve adequate improvement [1-3]. Copper containing dopamine, which catalyzes dopamine conversion from noradrenalin is a cofactor for beta hydroxylase. The reason for irritability and changes in behavior and consciousness in cases of vitamin C deficiency is the disruption of this tract [1]. Scurvy can be defined by bone pains and aversion to physical touch. The most important reason for this is subperiosteal hemorrhage and significant osteoporosis [4-8]. In scurvy, bone radiology has idiosyncratic characteristics, and typical images include significant osteoporosis, cortex as if drawn by a very fine-tipped pencil; central osteoporosis in metatarsus and metacarpus, circle-like image in the periphery with the fine cortex; transfers lines in metaphases (Frankel's line) (Figure 2). In the long-term, hip dislocations depending on hip dysplasia are common [1].

\section{Case Report}

A 2-year, 5-months old male child was admitted to the hospital with the complaints of growth retardation, lack of appetite, a preference to remain immobile, irritability. He was born in normal spontaneous birth as the first baby of the family. Family history revealed that the mother is a 25 -year old housewife, and healthy; the father was a 26-year old artisan, and healthy. It was learned that the patient had a 10-month old healthy brother and the parents were not related. The mother was still breastfeeding the younger baby. It was reported that the mother had goiter and the aunt (mother's sister) was a thalassemia carrier.

The first complaint identified in the patient, for which no medical examination was made, was a swelling in left hand middle finger proximal interphalangeal joint when the patent was 4 month old.
When the patient was 6 months old, due to limited mobility observed in his neck and other joints, the patient was taken to a state hospital within the local province. At this hospital, coarse facial appearance and hepatosplenomegaly was detected and the patient was referred to the hospital of the faculty of medicine in the vicinity with suspected metabolic disease. At this center, the patient was first examined by the child metabolism polyclinic when he was 13-month-old. In

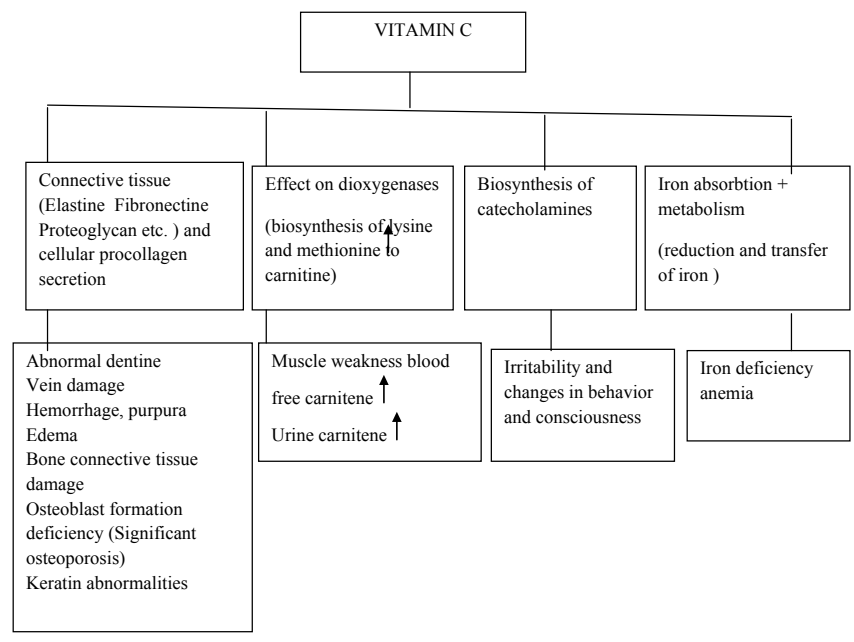

Figure 1: Vitamin C metabolic effects

*Corresponding author: Işı Özer, İstanbul Göztepe Eğitim Araştırma Hastanesi Çocuk Kliniği Kadıköy/ İstanbul/Türkiye, Tel: 02165666600 (work), 054237451 72 (mobile); Fax: +90216 56666 18; E-mail: ozer_isil@yahoo.com

Received March 30, 2012; Accepted April 21, 2012; Published April 23, 2012

Citation: Özer I, Kılınçı Z, Gökçay G, Baykal T, Demirkol M, et al. (2012) Forgotten Nutrıtıonal Dısease may Mımıc Metabolıc Dısorders Scurvy. J Nutr Disorders Ther 2:113. doi:10.4172/2161-0509.1000113

Copyright: (c) 2012 Özer I, et al. This is an open-access article distributed under the terms of the Creative Commons Attribution License, which permits unrestricted use, distribution, and reproduction in any medium, provided the original author and source are credited. 
examination, coarse facial appearance, macrocephaly, axial hypotonia, normal extremities and skin neurological retardation (lifting the head, sitting with support) were detected.

Gastroenterology consultation was requested to analyze the etiology of hepatosplenomegaly. The gastroenterology examination reported irritability, constantly crying, limited neck movement, long philtrum, hepatomegaly $(2 \mathrm{~cm})$ and normal spleen; however Lysosomal Storage Disease (LSD) detections were planned. LSD was excluded in terms of enzymes.

Since severe anemia was detected in laboratory tests, a homological evaluation was recommended. Iron deficiency was identified; the patient was recommended $6 \mathrm{mg} / \mathrm{kg} /$ day oral iron and was invited to a control examination after 1 month. A second hematologic evaluation was made when the patient was 17 months old. No improvement was observed in anemia despite 2 months of treatment. The bone marrow was analyzed and an increase in histiocytes and lack of storage cells and vacuolization was detected.

A follow-up was started in the Orthopedic Walking Analysis Laboratory in our university. Orthopedics planned to support him with pasive physical exercise treatment and then recommended a hip dislocation operation. They referred to our polyclinic the patient, because of his metabolic history. Examination in our polyclinic when the patient was 2 years and 5 months old found the following values: weight $8480 \mathrm{~g}(<3 \mathrm{p})$, height $81 \mathrm{~cm}(3 \mathrm{p})$, head circumference $48 \mathrm{~cm}$ (average $1+1$ standard deviation), weight/height proportion $76 \%$, height/age proportion $88 \%$. The patient was evaluated with acute and chronic moderate malnutrition. No edema, icterus, cyanosis, rash were present. Subcutaneous fat tissue was significantly decreased and looked pale. The patient had no lymphadenomegaly; the oropharynx was natural. The front 4 incisor teeth were dark-colored and blotchy. It was reported that the dark-colored stain in the teeth occurred after oral iron treatment. In examination of the respiratory system, diffuse secretion rales and crepitations were present by oscultation. Respiration rate was $35 / \mathrm{min}$. Cardiovascular system examination found peak heart rate was $96 / \mathrm{min}$, rhythmic S1 and, S2 normal, no S3, no souffle. Gastrointestinal system examination found that the patient was irritated by abdominal palpation; the both liver and spleen were palpable approximately 2 $\mathrm{cm}$ and moderate hardness. Traube was closed; Intestinal sounds were normoactive. Skeletal examination found that there were joint deformities and contractures in pectus carinatum, left hand thumb and middle finger proximal interphalangeal joint and foot joints (Figure 3 and 4). The neck was short and the patient was unable to move the neck. He was also unable to move his right hip bone, he felt comfortable when he pulled his legs to his abdomen and lay in a supine position. The patient did not let anyone touch his legs and cried when someone did so. He had swelling and limited movement in his hip, foot and wrist joints, which were reported to remain unchanged during the time; there was no temperature increase or redden. Neurological examination revealed that he was conscious; the patient was interested in the environment; bilateral pupillary isochoric light reflexes were equal. Deep tendon reflexes could not be evaluated due to contractures. Axial hypotonicity was present. Arm and leg muscles were atrophic. Examination of the urogenital system indicated that the patient was externally natural prepubertal male child.

From dietary report it was learned that the patient was breast-fed until 4 months; between 4-11 months he was weaned and therefore started to receive formula milk. Supplementary feeding was started with the water of the meals when the patient was 6 months old. $\mathrm{He}$ did not consume meat as he was unable to chew it. He consumed diary products and particularly liked yoghurt. He never consumed vegetables or fruit.

Dietary history of the patient revealed very poor consumption of vitamin $\mathrm{C}$ which was about $13 \%$ of recommended dietary allowances and had continued for a long period. Vitamin C level was $0.05 \mathrm{mg} / \mathrm{L}$ (n: 4-21) in plasma, $2.85 \mathrm{mg} / 24$ hour (n:10-30) in urine, and $1.03 \mathrm{mg} / 6$ hours in urine after intravenous loading. The patient was given $200 \mathrm{mg} /$ day vitamin $\mathrm{C}$ orally. Irritability and bone sensitivity decreased after the first two days and clinical improvement ensued.
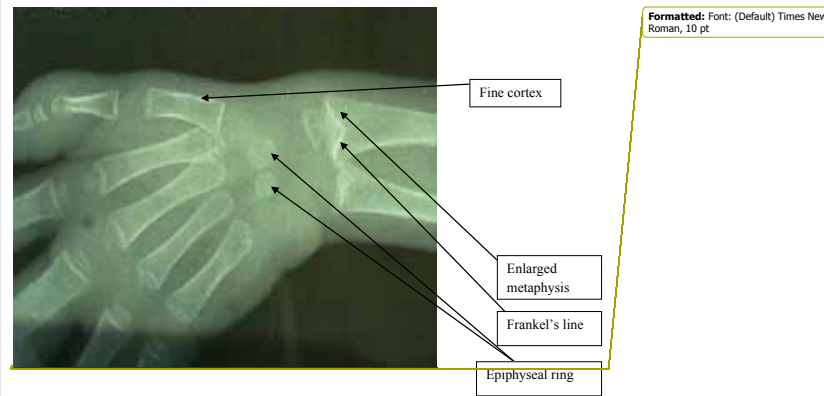

Figure 2: This figure showed characteristic bone radiologic findings for scurvy at hand and wrist bones.

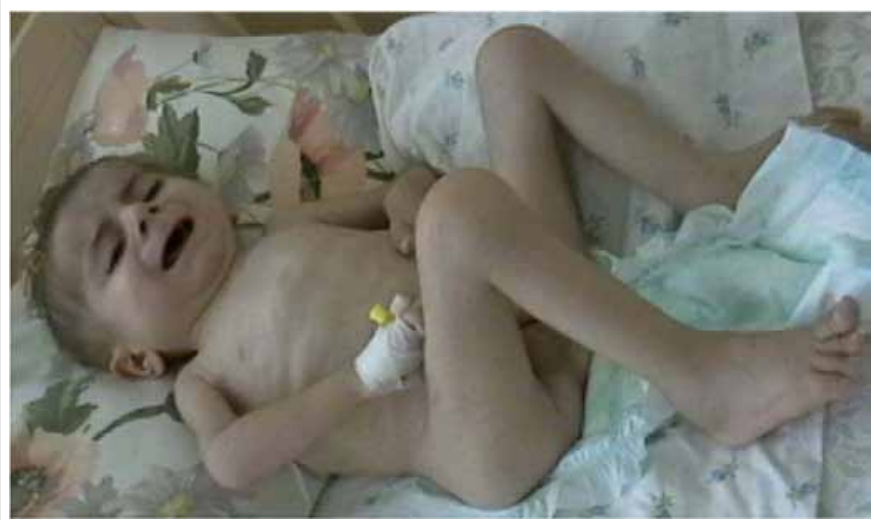

Figure 3: Patients irratibility, parasternal costal swellings, thorax deformities, wrists contractures and swellings.

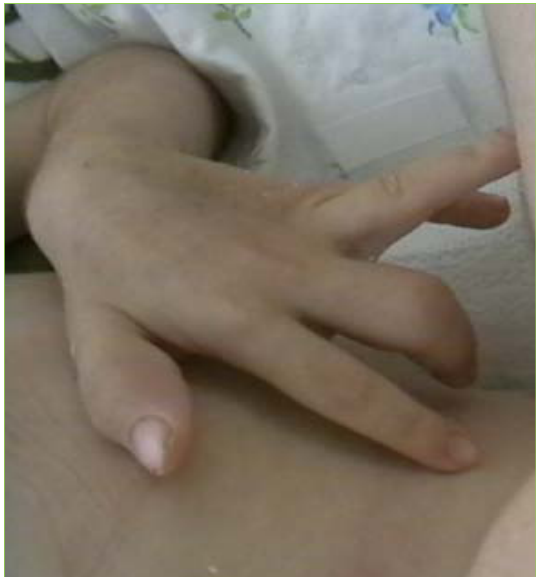

Figure 4: Contractures and swellings in hand bone. 


\section{Discussion}

When the history and physical examination are evaluated, the pathologic findings can be described as problems related to time quality and quantity of starting supplementary nutrition, severe malnutrition, mild psychomotor retardation, skeletal deformities, limited movement, coughing and wheezing, irritability, not letting anyone touch him, hepatosplenomegaly and treatment resistance iron deficiency anemia.

When the results of these detections were evaluated, there was nothing in the full blood count except significant microcytic anemia (Table 1). It was noted that during the 2 months in which the patient was followed after the iron deficiency treatment at the previous center, the treatment produced little response. Because of the aunt of the patient was a thalassemia carrier, his hemoglobin electrophoresis test is detected and was found normal.

When the blood and urine biochemistry of the patient was analyzed, no pathology was detected excluding trace amount of proteinuria. Control of thyroid hormone levels due to coarse facial appearance of the patient were between normal limits. Enzymatic detections for mucopolysaccharidosis, lysosomal storage diseases and mucolipidosis, which were considered and controlled in differential diagnosis due to coarse facial appearance and hepatosplenomegaly were between the normal limits. Following these findings, a diagnosis of storage disease

\begin{tabular}{|l|l|l|l|}
\hline Dedections & References limits & Initial & After treatment \\
\hline Leucocyte $10^{3} / \mu \mathrm{L}$ & $5500-15500$ & 9000 & 7600 \\
\hline Erithrocytex $10^{6} / \mu \mathrm{L}$ & $3.9-5.5$ & 4.42 & 4.53 \\
\hline Hemoglobin $\mathrm{g} / \mathrm{dl}$ & $11.3-14.1$ & 7.4 & 8.9 \\
\hline Hematocrite \% & $33.0-40.0$ & 24.2 & 27.9 \\
\hline MCV fL & $73-87$ & 54 & 62 \\
\hline MCHb pg & $23-31$ & 16.6 & 19.7 \\
\hline Platelet $\times 10^{3} / \mu \mathrm{L}$ & $170-380$ & 608 & 466 \\
\hline ESR $\mathrm{mm} / \mathrm{hour}$ & & 88 & 20 \\
\hline
\end{tabular}

ABBREVIATIONS. MCV, Mean corpuscular volume; MCHb, Mean corpuscula hemoglobine; ESR, Eritrocyte sedimentation rate

Table 1: Routine laboratory detections result at initial and after specific treatment.

\begin{tabular}{|c|c|c|c|}
\hline Dedections & References limits & Initials & After treatments \\
\hline \multicolumn{4}{|l|}{ Urine aminoacids } \\
\hline Asparagine $\mathrm{nmol} / \mathrm{ml}$ & $<53$ & 410 & 32 \\
\hline Glycine $\mathrm{nmol} / \mathrm{ml}$ & $<1$ & 6251 & 0 \\
\hline Arginine $\mathrm{nmol} / \mathrm{ml}$ & $\leq 13$ & 12.4 & 0 \\
\hline Valine $\mathrm{nmol} / \mathrm{ml}$ & $5-20$ & 36 & 17,3 \\
\hline Ornitine $\mathrm{nmol} / \mathrm{ml}$ & $\leq 1$ & 611 & 0 \\
\hline Serine $\mathrm{nmol} / \mathrm{ml}$ & $30-148$ & 241 & 159 \\
\hline Treonine $\mathrm{nmol} / \mathrm{ml}$ & $10-89$ & 92 & 39.1 \\
\hline Metionine $\mathrm{nmol} / \mathrm{ml}$ & $2-9$ & 6.5 & 4.35 \\
\hline Lysine $\mathrm{nmol} / \mathrm{ml}$ & $\leq 92$ & 132 & 52.3 \\
\hline Citrulline $\mathrm{nmol} / \mathrm{ml}$ & $\leq 1$ & 0.83 & 0 \\
\hline Argininosuccinate $\mathrm{nmol} / \mathrm{ml}$ & $\leq 1$ & 9.9 & 0 \\
\hline \multicolumn{4}{|l|}{ Serum aminoacids } \\
\hline Asparagine $\mathrm{nmol} / \mathrm{ml}$ & $24-64$ & 34.13 & 41.8 \\
\hline Serine $\mathrm{nmol} / \mathrm{ml}$ & $77-169$ & 151.8 & 159 \\
\hline Glycine $\mathrm{nmol} / \mathrm{ml}$ & $113-261$ & 201.8 & 234 \\
\hline Treonine $\mathrm{nmol} / \mathrm{ml}$ & $48-140$ & 73.3 & 67.5 \\
\hline Arginine $\mathrm{nmol} / \mathrm{ml}$ & $38-98$ & 98 & 87 \\
\hline Metionine $\mathrm{nmol} / \mathrm{ml}$ & $11-47$ & 13.3 & 16.9 \\
\hline Ornitine nmol/ml & $24-64$ & 67.7 & 111 \\
\hline Citrulline $\mathrm{nmol} / \mathrm{ml}$ & $18-50$ & 20 & 23 \\
\hline Lysine $\mathrm{nmol} / \mathrm{ml}$ & $52-196$ & 128.4 & 133 \\
\hline
\end{tabular}

Table 2: Metabolic detections results at initial and after specific treatment. was eliminated. However, urine quantitative amino acid analysis due to malnutrition and significant osteoporosis indicated that many amino acids, particularly lysine, were discharged in high levels. However, serum lysine level was not deficient (Table 2). In addition, there was a slight increase in carnitine which is not expected from a malnutrition patient. A bone graph taken for skeletal deformities indicated significant osteoporosis, enlargement in metaphases and thinning in the cortex (Figure 2); serum vitamin D level was at normal limits.

Findings related to joint problems, irritability, not letting anyone touch him and dietary history, serum and urine vitamin $C$ levels made us consider vitamin $\mathrm{C}$ deficiency despite the lack of skin and teeth findings.

Although scurvy is considered to be a problem of non-developed countries, research on western societies revealed that this disease was not rare [9-11]. There has been no comprehensive survey on vitamin $\mathrm{C}$ level in Turkey. However, this case suggests that the prevalence of vitamin $\mathrm{C}$ deficiency is higher than assumed, due to mistakes in starting supplementary foods. This case report was presented to draw attention to this disease, which is overlooked due to assumptions that it is rare, and to emphasize the importance of dietary history in accurate diagnosis.

\section{Conclusion}

Clinical features in scurvy resemble symptoms observed in some metabolic disorders. Careful clinical evaluation, dietary history and vitamin $\mathrm{C}$ assay may exclude unnecessary metabolic work-up.

\section{References}

1. Kupka R, Villamor E, Fawzi W (2008) Vitamins: Nutrition in pediatrics. $\left(4^{\text {th }}\right.$ edn. $)$, BC Decker Inc, Ontario.

2. Weinstein M, Babyn P, Zlotkin S (2001) An Orange a Day Keeps the Doctor Away: Scurvy in the Year 2000. Pediatrics 108: E55.

3. Pimentel L (2003) Scurvy: Historical Review and Current Diagnostic Approach Am J Emerg Med 21: 328-332.

4. Rosati P, Boldrini R, Devito R, Menditto A, Barbuti D, et al. (2005) A child with painful legs. Lancet 365: 1438.

5. Popovich D, McAlhany A, Adewumi AO, Barnes MM (2009) Scurvy: Forgotten but definitely not gone. J Pediatr Health Care 23: 405-415.

6. Olmedo JM, Yiannias JA, Windgassen EB, Gornet MK (2006) Scurvy: a disease almost forgotten. Int J Dermatol 45: 909-913.

7. Li R, Byers K, Walvekar RR (2008) Gingival hypertrophy: a solitary manifestation of scurvy. Am J Otolaryngol 29: 426-428.

8. Heymann WR (2007) Scurvy in children. J Am Acad Dermatol 57: 358-359.

9. Duggan CP Westra SJ, Rosenberg AE (2007) Case records of the Massachusetts General Hospital. Case 23-2007. A 9-year-old boy with bone pain, rash, and gingival hypertrophy. N Engl J Med 357: 392-400.

10. Narchi H, Thomas M (2000) A painful limp. J Paediatr Child Health 36: 277-278

11. Fain O (2005) Musculoskeletal manifestations of scurvy. Joint Bone Spine 72 124-128. 